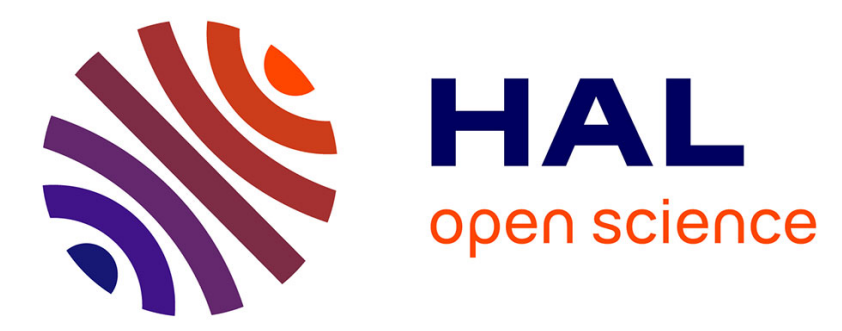

\title{
Cadmium-induced oxidative damages in the human BJAB cells correlate with changes in intracellular trace elements levels and zinc transporters expression \\ Saïd Nemmiche, Pascale Guiraud
}

\section{- To cite this version: \\ Saïd Nemmiche, Pascale Guiraud. Cadmium-induced oxidative damages in the human BJAB cells cor- relate with changes in intracellular trace elements levels and zinc transporters expression. Toxicology in Vitro, 2016, 37, pp.169 - 177. 10.1016/j.tiv.2016.09.014 . hal-01397509}

\section{HAL Id: hal-01397509 \\ https://hal.univ-reunion.fr/hal-01397509}

Submitted on 16 Nov 2016

HAL is a multi-disciplinary open access archive for the deposit and dissemination of scientific research documents, whether they are published or not. The documents may come from teaching and research institutions in France or abroad, or from public or private research centers.
L'archive ouverte pluridisciplinaire HAL, est destinée au dépôt et à la diffusion de documents scientifiques de niveau recherche, publiés ou non, émanant des établissements d'enseignement et de recherche français ou étrangers, des laboratoires publics ou privés. 


\title{
Cadmium-induced oxidative damages in the human BJAB cells correlate with changes in intracellular trace elements levels and zinc transporters expression
}

\author{
Saïd Nemmiche ${ }^{\mathrm{a}, *}$, Pascale Guiraud ${ }^{\mathrm{b}}$ \\ a LSTPA Laboratory, Department of Biology, Faculty of SNV, University of Mostaganem, \\ Mostaganem 27000, Algeria \\ b Université de La Réunion, CNRS 9192, INSERM U1187, IRD 249, Unité Mixte Processus Infectieux en \\ Milieu Insulaire Tropical (PIMIT), Plateforme Technologique CYROI, Sainte-Clotilde, La Réunion, \\ France
}

\begin{abstract}
A B S T R A C T
Cadmium (Cd), a potent toxic heavy metal, is a widespread environmental contaminant. Its cellular traffic via pathways dedicated to transition metals contributes to the toxicity mechanisms. Zinc (Zn) homeostasis is complex, involving both zinc importers (Zip) and zinc exporters (ZnT). Cellular signal transduction pathways are influenced by $\mathrm{Zn}$ and redox status of the cell. The aim of the present study is to examine if the accumulation of $\mathrm{Cd}$ in the human lymphocyte B cell line BJAB and its capacity to promote oxidative stress and adverse effects could re-sult from changes in the mRNA expression pattern of $\mathrm{Zn}$ transporters and metallothioneins. Cells were exposed to 5, 10, 20 and $40 \mu \mathrm{M}$ of $\mathrm{CdCl}_{2}$ equivalent to $0.91,1.83,3.66$ and $7.33 \mu \mathrm{g} / \mathrm{ml}$ respectively, for $24 \mathrm{~h}$. Cd significantly reduced the viability of BJAB cells and induced a dose-dependent increase in DNA damage. Cd also induced the formation of 8-hydroxy-2'-deoxyguanosine adducts and augmented MTF1 expression in BJAB cells. We observed interesting responses in relative gene expression to $\mathrm{Cd}$ exposure among the seven transporters we analyzed. Cd exposure increased the expression of DMT1 and caused an up-regulation of ZnT1. However, the T calcium chan-nel alpha1G subunit could not be detected. A change in expression of ZnTs and Zips in response to $\mathrm{Cd}$ exposure emphasizes the involvement of $\mathrm{Zn}$ transporters in $\mathrm{Cd}$ cellular metabolism and induced oxidative stress.
\end{abstract}

\section{Introduction}

Cadmium (Cd) is a widespread environmental and industrial pollutant which has been classified as a type I carcinogen by the International Agency for Cancer Research (IARC, 1993). The major sources of this environmental toxic heavy metal for humans are cigarette smoke and food. It is known to cause renal dysfunction, hepatic toxicity, genotoxicity and apoptotic effects depending on the dose, route and duration of exposure. Cd was shown to provoke a number of responses in the cells that involve not only death signaling but also protective reactions against the toxicity (Luparello et al., 2010; Nemmiche et al., 2012). It acts as an immunomodulator at sub-toxic concentrations (Haase et al., 2010) and many of its effects are mediated by oxidative mechanisms.

The mechanisms involved in the transport and handling of $\mathrm{Cd}$ in target cells are not well defined. It can be transported and taken up by cells

Abbreviations: Zip, Zrt- and Irt-like (SLC39A) proteins; ZnT, solute-linked carrier 30 (SLC30A) proteins; DMT1, divalent metal-ion transporter 1; MTF1, metal-responsive transcription factor 1; MT, Metallothionein; MRE, metal response element; 8-OHdG, 8 Oxo-deoxyguanosine.

* Corresponding author at: B.P. 567 Mostaganem RP, 27000 Mostaganem, Algeria.

E-mail address: snemiche@hotmail.com (S. Nemmiche). by a process referred to as "ionic and molecular mimicry" (Bridges and Zalups, 2005). Cd appears to be capable of utilizing certain transporter(s) of $\mathrm{Zn}^{2+}$ and some transport systems sensitive to $\mathrm{Ca}^{2+}$ and $\mathrm{Fe}^{2+}$. Transition metals such as iron, zinc, manganese, and copper have numerous biological roles as both structural and catalytic cofactors for proteins and therefore these metals are essential for life. However, the same elements become toxic whenever excessive intracellular accumulation occurs. The redox activity seems to play a driving role in addressing the main effects of these trace metals. The perturbation of the homeostasis of physiological trace elements could be the basis of many of the deleterious effects of Cd (Nemmiche et al., 2011). Cellular signal transduction pathways are influenced by zinc $(\mathrm{Zn})$ and the redox status of the cell. $\mathrm{Zn}$ is an essential trace element that serves as a cofactor for various enzymes involved in either macromolecule synthesis or protein metabolism. Normal cellular homeostasis requires appropriate $\mathrm{Zn}$ transport and storage. Mammalian $\mathrm{Zn}$ transporters are within two gene families: (a) the ZnT proteins [solute-linked carrier 30 (SLC30)] and (b) the Zip proteins (Zrt- and Irt-like proteins) family [solute-linked carrier 39 (SLC39)] (Liuzzi and Cousins, 2004). In this regard, $10 \mathrm{Zn}$ exporters (ZnT) and $15 \mathrm{Zn}$ importers (Zip) have been described. Both transcriptional and post-translational regulation can affect protein abundance and cellular localization of these transporters. 
They are also involved in the traffic of other metals (Lichten and Cousins, 2009). Numerous studies on Cd influx into cells have been carried out. Among the members of ZIP family, ZIP8 and ZIP14 $\left(\mathrm{Zn}^{2+} / \mathrm{HCO}_{3}^{-}\right.$ symporters) have been reported to transport Cd in kidney, intestine and testis (He et al., 2009; Fujishiro et al., 2011). Cd is also taken up via the voltage-sensitive $\mathrm{Ca}^{2+}$ and $\mathrm{Mg}^{2+}$ channels of the plasma membrane (Lévesque et al., 2008); decreased expression of the T-type $\mathrm{Ca}^{2+}$ channel protects cells from $\mathrm{Cd}$ exposure by limiting Cd uptake in Cd-resistant MT-I/II knockout cells (Leslie et al., 2006). Other transporters of divalent metals have also been implicated in the uptake of $\mathrm{Cd}$ by selective epithelial cells in the kidneys, liver, intestines (Zalups and Ahmad, 2003) and osteoblast (Martineau et al., 2010). Among human leukocyte subsets, ZnT1 transcripts are more abundant in monocytes than T-lymphocytes or neutrophils (Cousins et al., 2006). The critical targets of Cd binding are the thiol groups of proteins. $\mathrm{Cd}^{2+}$ is a soft Lewis acid, which binds to thiols with even higher affinity than $\mathrm{Zn}^{2+}$.

Metallothioneins (MTs) are cysteine-rich, low molecular weight proteins that bind many metal ions and are also closely connected to stress-sensing pathways. It should be noted that MTs may be induced by several metals. Humans possess 16 known isoforms of MTs, grouped into four classes: MTs I, II, III, and IV. MT-1 and MT-II are ubiquitously present in all organs of mammals. The expression of MT-I/II mRNA in blood and peripheral lymphocytes has recently been used as a sensitive biomarker of environmental and occupational exposure to $\mathrm{Cd}$ in human population (Chang et al., 2009). MTs are involved in many cellular functions such as essential metal transport and storage, heavy metal detoxification, and protection against oxidative stress.

To understand the mechanism of cadmium accumulation in the lymphocyte, it is important to know the mechanisms of its transport systems. The aim of this study is to investigate the biological effect of cadmium (Cd) on human BJAB cells, especially on other metals accumulation, cellular redox status and $\mathrm{Zn}$ transporter expressions.

The form of $\mathrm{Cd}$ and the route of environmental exposure can greatly affect the absorption and distribution of $\mathrm{Cd}$ to various target sites, and therefore, the concentration at the target site and the severity of the observed effect. Cd chloride was given in selected doses, which are the optimal for producing effects as determined in previous studies (Nemmiche et al., 2007, 2011). According to our knowledge, no similar studies have been conducted in BJAB cells.

\section{Materials and methods}

\subsection{Cell culture and chemical treatment}

BJAB cells were cultured in RPMI-1640 medium supplemented with $15 \%$ heat-inactivated fetal bovine serum (Sigma), 100 units/ml penicillin, $100 \mu \mathrm{g} / \mathrm{ml}$ streptomycin, and $2 \mathrm{mM}$ L-glutamine at $37^{\circ} \mathrm{C}$ in a humidified incubator with $5 \% \mathrm{CO}_{2}$. Cadmium chloride $\left(\mathrm{CdCl}_{2}\right)$ was dissolved in distilled water to prepare a $10 \mathrm{mM}$ stock solution, and was filter-sterilized $(0.22 \mu \mathrm{m})$ before being added to the culture media. This solution was further diluted with the medium ( $\mathrm{pH} 7.4$ ) to the desired concentrations. Cultures were suspended in a fresh batch RPMI-1640 before exposing the cells to various cadmium chloride concentrations: $5,10,20$ and $40 \mu \mathrm{M}$ equivalent at $0.91,1.83,3.66$ and $7.33 \mu \mathrm{g} / \mathrm{ml}$ respectively, for $24 \mathrm{~h}$. The selected doses of $\mathrm{Cd}$ is made on the basis of the cytotoxicity test (03 concentrations chosen $(5,10$ and $20 \mu \mathrm{M}$ ) with a rate of viability $>70 \%) .24$ h was chosen because our previous study showing that disruption of redox homeostasis by $\mathrm{Cd}$ was optimal at $24 \mathrm{~h}$ (Nemmiche et al., 2011).

\subsection{MTT assay}

Cytotoxicity induced by cadmium was assessed by MTT assay (Naha et al., 2010). Tetrazolium salt, 3-(4,5-dimethylthiazol-2-yl)-2,5diphenyle tetrazolium bromide (MTT), is reduced by intracellular dehydrogenase of viable living cells, that leads to formation of purple formazan crystals, insoluble in aqueous solutions. Following exposure to cadmium chloride, $100 \mu \mathrm{l}$ of $0.5 \%$ MTT was added to the culture media and cells were incubated for an additional $2 \mathrm{~h}$ at $37^{\circ} \mathrm{C}$ in a humidified atmosphere containing $5 \% \mathrm{CO}_{2}$. After this incubation, formed formazan was solubilized by adding dimethyl sulfoxide, and optical density was measured at $570 \mathrm{~nm}$ using UV-160A Shimadzu spectrophotometer.

\subsection{Sample preparation for antioxidant enzymes activity, glutathione level and malondialdehyde level}

After the indicated treatments with cadmium, cells were collected. The pellets obtained after centrifugation $\left(1400 \times \mathrm{g}\right.$ for $3 \mathrm{~min}$ at $\left.4{ }^{\circ} \mathrm{C}\right)$ were resuspended in isotonic Tris- $\mathrm{HCl}$ buffer $(400 \mathrm{mM}, 300 \mathrm{mOsm}$, $\mathrm{pH} 7.3$ ) centrifuged and rinsed twice with the Tris- $\mathrm{HCl}$ buffer. Then cells were lysed in hypotonic Tris- $\mathrm{HCl}$ buffer $(20 \mathrm{mM}, \mathrm{pH} 7.3)$ by five freeze-thaw cycles $\left(5 / 10^{\prime},-196{ }^{\circ} \mathrm{C} / 37^{\circ} \mathrm{C}\right)$. For glutathione and thiol group determination, aliquots were taken from the whole homogenized lysate. The other determinations were performed on the supernatants obtained after centrifugation of the lysates. The extracts were stored at $-80^{\circ} \mathrm{C}$, until analyses.

\subsection{Intracellular cadmium and trace element analysis}

After $24 \mathrm{~h}$ incubation with $\mathrm{Cd}$, the BJAB cells were collected and washed three times in physiological $\mathrm{NaCl}(0.9 \%)$. Then the pellet was resuspended in deionized water (Naha et al., 2015) and the cells were lysed by five freeze/thaw $\left(-196{ }^{\circ} \mathrm{C} / 37^{\circ} \mathrm{C}\right)$ cycles. The lysates (total extract) were centrifuged at $4000 \times \mathrm{g}$ for $10 \mathrm{~min}$ at $4{ }^{\circ} \mathrm{C}$ to obtain the soluble fraction.

The intracellular $\mathrm{Cd}$ and essential metal concentrations were determined by inductively coupled plasma mass spectrometry (ICP/MS) (Thermo-Electron X) and the detection limit was $72 \mathrm{nmol} \mathrm{Cd}, 1 \mathrm{nmol}$ Se, $52 \mathrm{nmol} \mathrm{Zn,} 110 \mathrm{nmol} \mathrm{Cu}, 34 \mathrm{nmol} \mathrm{Fe}$, and 2 nmol Mn per liter. Their levels were normalized to the protein content, measured with a protein assay kit (Pierce, USA).

\subsection{Antioxidant enzyme activity assays}

\subsubsection{Catalase activity}

Catalase (CAT) activity was measured according to Beers and Sizer (1952). The rate of $\mathrm{H}_{2} \mathrm{O}_{2}$ decomposition by CAT was followed at $240 \mathrm{~nm}$. One unit is defined as $1 \mu \mathrm{mol}$ of $\mathrm{H}_{2} \mathrm{O}_{2}$ consumed per minute and the specific activity is reported as units per milligram of protein.

\subsubsection{Superoxide dismutase activity}

Superoxide dismutase (SOD) activities (total SOD, Cu/ZnSOD and MnSOD) were measured using the pyrogallol assay according to the method described by Marklund and Marklund (1974), based on the competition between pyrogallol oxidation by superoxide radicals and superoxide dismutation by SOD. The specific $\mathrm{Cu} / \mathrm{ZnSOD}$ inhibition by potassium cyanide allowed the MnSOD determination in the same conditions. Assays were monitored by spectrophotometry at $420 \mathrm{~nm}$. One unit of SOD activity is defined as the amount of the enzyme required to inhibit the rate of pyrogallol auto-oxidation by 50\%. SOD activities were expressed as international units per $\mathrm{mg}$ of soluble cell proteins.

\subsubsection{Glutathione peroxidase activity}

Glutathione peroxidase (GPx) activity was determined by the method of Flohe and Gunzler (1984). The rate of glutathione oxidized by tertbutyl hydroperoxide was evaluated by the decrease of NADPH at $340 \mathrm{~nm}$ in the presence of EDTA, excess reduced glutathione and glutathione reductase. GPx activity was expressed in terms of $\mu \mathrm{M}$ NADPH oxidized per minute per milligram of soluble cell proteins. 


\subsection{Oxidative stress parameters}

\subsubsection{Glutathione level}

The sum of the reduced and oxidized forms of glutathione were determined spectrophotometrically using the method described by Akerboom and Sies (1981), based on the kinetic assay in which catalytic amounts of GSH or GSSG and glutathione reductase bring about the continuous reduction rate of 5,5'-dithiobis-2-nitrobenzoic acid (DTNB, Sigma, France) into 5-thio-2-nitrobenzoic acid (TNB) by NADPH. Briefly, samples of whole lysates were deproteinized with metaphosphoric acid (6\%) and the mixture was centrifuged at $4000 \mathrm{rpm}$ for $10 \mathrm{~min}$ at $4{ }^{\circ} \mathrm{C}$. Pipet into a thermostated cuvette $\left(25^{\circ} \mathrm{C}\right): 1 \mathrm{ml}$ of potassium phosphate buffer, $0.1 \mathrm{M}$ (pH 7.0) containing $1 \mathrm{mM}$ EDTA, $100 \mu \mathrm{l}$ sample, $50 \mu \mathrm{l}$ of $4 \mathrm{mg} / \mathrm{ml} \mathrm{NADPH}$ in $0.5 \% \mathrm{NaHCO}_{3}, 20 \mu \mathrm{l}$ of $1.5 \mathrm{mg} / \mathrm{ml} \mathrm{DTNB}$ in $0.5 \%$ $\mathrm{NaHCO}_{3}$ and $20 \mu \mathrm{l} \mathrm{GSH}$ reductase ( 6 units/ml). The absorbance was measured for $1 \mathrm{~min}$ at $412 \mathrm{~nm}$. Results were expressed as $\mu \mathrm{mol}$ per gram of total cell proteins.

\subsubsection{Malondialdehyde (MDA) assay}

Lipid peroxidation (LPO) was evaluated by the thiobarbituric acid reacting substance (TBARS) and was expressed in terms of malondialdehyde (MDA) content. Sample aliquots were incubated with $10 \%$ trichloroacetic acid and $0.67 \%$ thiobarbituric acid. The mixture was heated on a boiling water bath for $30 \mathrm{~min}$, an equal volume of $n$-butanol was added, and the final mixture was centrifuged; the organic phase was collected for fluorescence measurements at $532 \mathrm{~nm}$. Samples assayed for MDA contained $1 \mathrm{mM}$ butylated hydroxytoluene (BHT) in order to prevent arte factual LPO during the boiling step. Results were expressed as $\mu \mathrm{mol}$ MDA per gram of soluble cell proteins.

\subsubsection{Single cell gel electrophoresis (Comet assay)}

The single cell gel electrophoresis assay (SCGE) or comet assay (Naha and Byrne, 2013) used for the detection of single strand DNA breaks in individual BJAB cells after exposure to cadmium chloride.

Control cells and cells exposed to cadmium were collected, pelleted, resuspended in PBS and mixed with low-melting-point agarose $(1 \%, \mathrm{w} / \mathrm{v})$, then transferred to the layer of agarose, covered with a cover slip and the slides placed on ice. The cover slips were then removed and the slides were immersed in a lysis buffer $(2.5 \mathrm{M} \mathrm{NaCl}$, $100 \mathrm{mM} \mathrm{Na} 2$ EDTA, $10 \mathrm{mM}$ Tris- $\mathrm{HCl}, 1 \%(\mathrm{w} / \mathrm{v})$ sodium sarcosinate, pH 10; $1 \%$ Triton X-100 and 10\% DMSO added just before use) in the dark at $4{ }^{\circ} \mathrm{C}$. Then the slides were placed in a horizontal electrophoresis unit containing freshly-prepared alkaline electrophoresis buffer (200 $\mathrm{mM} \mathrm{Na}_{2}$ EDTA, $10 \mathrm{M} \mathrm{NaOH}$ ). The DNA was allowed to unwind for $40 \mathrm{~min}$ before electrophoresis was performed at $25 \mathrm{~V}, 300 \mathrm{~mA}$ for $30 \mathrm{~min}$. After neutralization (0.4 M Tris- $\mathrm{HCl}, \mathrm{pH} 7.5)$, the DNA was stained with $50 \mu \mathrm{L}$ of $20 \mu \mathrm{g} \mathrm{ml}{ }^{-1}$ ethidium bromide pipetted onto the slides. The slides were then placed in a humidified air-tight container to prevent drying of the gel, before the analysis. Comets were scored using a fluorescence microscope from Leitz (Germany) and the kinetic imaging software (Komet 4, Kinetic Imaging Ltd., Liverpool). Fifty cells were scored per each of three replicate slides and results were expressed as tail DNA (percentage of DNA in tail).

\subsubsection{Metallothionein analysis}

Metallothionein protein expression in BJAB cells was quantified with Western blots by the method of Mizzen et al. (1996). Cells were collected, washed three times with cold phosphate-buffered saline (PBS, $\mathrm{pH} 7.4$ ), resuspended on ice in lysis buffer containing $0.5 \%$ Triton X-

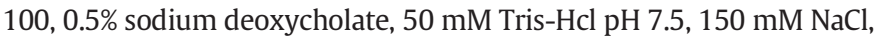
$2 \mathrm{mM}$ EDTA and a protease inhibitor mixture ( $1 \mathrm{mM}$ pefabloc, $2 \mu \mathrm{g} / \mathrm{ml}$ aprotinin, $10 \mu \mathrm{g} / \mathrm{ml}$ pepstatin and complete EDTA free tablet). The lysate was then homogenized and centrifuged at $4{ }^{\circ} \mathrm{C}$. After centrifugation, protein concentration of the supernatant was determined by using BCA protein assay kit (Pierce).
Equal amount of cell lysate proteins were mixed with 2-fold concentrated Laemmli loading sample buffer, heated for $5 \mathrm{~min}$ at $100{ }^{\circ} \mathrm{C}$ and then subjected to electrophoresis using 15\% SDS-polyacrylamide gels. Separated proteins were transferred onto nitrocellulose membrane (Bio-Rad) by electroblotting and non-specific binding sites were blocked in $10 \%$ non-fat dried milk in the TBST buffer $(20 \mathrm{mM}$ Tris- $\mathrm{HCl}$, $\mathrm{pH} 7.4,154 \mathrm{mM} \mathrm{NaCl}$ and $0.1 \%(\mathrm{v} / \mathrm{v}$ ) Tween 20). The membrane was then incubated overnight with the primary antibody monoclonal mouse anti-horse metallothionein (diluted at 1:1000) (Dako, clone E9, France). Afterwards, membranes were incubated for $4 \mathrm{~h}$ at room temperature with horseradish peroxidase goat anti-mouse IgG (Bio-Rad, France) antibody (1:1000) in Tween-TBS. After washing, immunocomplexes on the membranes were visualized with the ECL®plus (enhanced chemiluminescence plus) Western blotting detection reagents (Amersham Biosciences, U.K.). Relative protein levels were determined by using the Gel-Pro analyser software version 4.

\subsection{DNA extraction from cells and HPLC-EC analysis}

For DNA oxidation assay, cells were plated at a concentration of $20 \times 10^{6}$ per flask. Each cell culture flask was homogenized in $2 \mathrm{~mL}$ of lysis buffer ( $320 \mathrm{mM}$ sucrose, $10 \mathrm{mM}$ Tris- $\mathrm{HCl}, 5 \mathrm{mM} \mathrm{MgCl} 2,0.1 \mathrm{mM}$ deferoxamine, $1 \%$ Triton $\mathrm{X}-100, \mathrm{pH} 7.5$ ) and centrifuged at $1500 \times \mathrm{g}$ for $10 \mathrm{~min}$. The supernatant was discarded and the nuclear pellet was suspended in $600 \mu \mathrm{l}$ of an extraction buffer (10 mM Tris-HCl, $5 \mathrm{mM}$ $\mathrm{Na}_{2}$ EDTA, and $0.15 \mathrm{mM}$ deferoxamine). Subsequently, 10\% SDS (35 $\mu \mathrm{l}$ ) was added. Ribonuclease A and RNase T1 were then added and the resulting suspension gently vortexed for $10 \mathrm{~s}$. The samples were incubated at $50{ }^{\circ} \mathrm{C}$ for $15 \mathrm{~min}$. Then, $30 \mu \mathrm{L}$ of Qiagen protease $(20 \mathrm{mg} / \mathrm{ml})$ was added, and the samples gently vortexed for $10 \mathrm{~s}$ prior to being incubated for $1 \mathrm{~h}$ at $37^{\circ} \mathrm{C}$.

DNA was precipitated by the addition of $0.8 \mathrm{~mL}$ of $\mathrm{NaI}$ solution (20 mM Na${ }_{2}$ EDTA, 7.6 M NaI, $40 \mathrm{mM}$ Tris-HCl, and $0.3 \mathrm{mM}$ deferoxamine) and $2 \mathrm{~mL}$ of $100 \%$ propan-2-ol. DNA was centrifuged at $5000 \times g$ for $10 \mathrm{~min}$ and washed with $1 \mathrm{~mL}$ of $40 \%$ propan-2-ol and $1 \mathrm{~mL}$ of $70 \%$ ethanol. DNA was then dissolved in $100 \mu \mathrm{L}$ of $0.1 \mathrm{mM}$ deferoxamine.

After DNA extraction, enzymatic hydrolysis was performed at $37{ }^{\circ} \mathrm{C}$ for 90 min using 10 units of nuclease P1 and 0.5 unit of acidic phosphatase dissolved in $10 \mu \mathrm{L}$ of nuclease P1 buffer [ $300 \mathrm{mM}$ sodium acetate, $1 \mathrm{mM} \mathrm{ZnSO}_{4}, 2.5 \mathrm{mM}$ deferoxamine, $\mathrm{pH}$ 5.3]. Thereafter, $50 \mu \mathrm{L}$ of chloroform was added to precipitate proteins. The aqueous layer was collected and analyzed by HPLC-EC system (Gedik and Collins, 2005).

The mobile phase consisted of phosphate buffer $(50 \mathrm{mM}, \mathrm{pH} 5.5)$ containing $12 \%$ methanol, and HPLC separation was run at $26^{\circ} \mathrm{C}$ after appropriate calibration. 8-Oxo-deoxyguanosine (8-OHdG) was eluted at $12 \mathrm{~min}$ and desoxyguanosine (dG) eluted at $9 \mathrm{~min}$. The data are expressed as the percentage of $8-\mathrm{OHdG} / 10^{5} \mathrm{dG}$ compared with control.

\subsection{Extraction of total RNA and quantitative RT-PCR analysis}

Quantification of mRNA levels of transporters (Zips, ZnTs and DMT1) and MTF1 (Table 1) was performed by real-time RT-PCR using a Stratagene Mx3005Pтм. Total RNA was extracted from cells pellets, with RNeasy ${ }^{\circledR}$ Mini kit (Qiagen, Saint Louis, USA) according to the manufacturer's recommendations. From $2 \mu \mathrm{g}$ of total RNA, cDNAs were synthesized using SuperScript ${ }^{\mathrm{TM}}$ III First-Strand Synthesis Supermix kit (Invitrogen). qRT-PCR was performed in a MicroAmp optical 96-well plate with the QuantiTect SYBR Green RT-PCR kit (Qiagen). Thermal profile were set as follows: $95^{\circ} \mathrm{C}$ for $15 \mathrm{~min}$, and 40 cycles of $94{ }^{\circ} \mathrm{C}$ for $15 \mathrm{~s}, 60^{\circ} \mathrm{C}$ for $30 \mathrm{~s}$, and $72{ }^{\circ} \mathrm{C}$ for $30 \mathrm{~s}$.

The primers used for RPL27 (ribosomal protein L27; 60S ribosomal protein L27 [Homo sapiens]: GenBank Accession NM_000988) as an internal control. 
Table 1

Primers used for zinc transporters expression study

\begin{tabular}{|c|c|c|c|}
\hline $\begin{array}{l}\text { Symbol } \\
\text { Gene description }\end{array}$ & GenBank accession & Sequence $\left(5^{\prime}->3^{\prime}\right)$ & Location \\
\hline MTF1 & \multirow[t]{2}{*}{ NM_005955 } & Forward GGACAGTGCGGAGAACACTT & $193-212$ \\
\hline Metal-regulatory transcription factor 1 [Homo sapiens] & & Reverse GTGGAACCAGGGTTTATTGTCA & $335-314$ \\
\hline DMT & \multirow[t]{2}{*}{ NM_000578 } & Forward GCCCTGTCCGTCTCCTTTATC & $871-891$ \\
\hline Solute carrier family 11 (proton-coupled divalent metal ion transporters) & & Reverse TGTTGGCACAGATGTTGAACG & $973-953$ \\
\hline SLC39A1 = ZIP1 & \multirow[t]{2}{*}{ NM_014437 } & Forward ACTACCTGGCTGCCATAGATG & $272-292$ \\
\hline Solute carrier family 39 (zinc transporter), member 1 & & Reverse GCCCTGACTGCTCCTTGTAAG & $415-395$ \\
\hline SLC39A3 = ZIP3 & \multirow[t]{2}{*}{ NM_144564 } & Forward TGGCCGAAACCATCCTCCT & $257-275$ \\
\hline Solute carrier family 39 (zinc transporter), member 3 & & Reverse GATCCGGCGTTGAAGGTCTC & $374-355$ \\
\hline SLC39A8 = ZIP8 & \multirow[t]{2}{*}{ NM_022154 } & Forward TGCTACCCAAATAACCAGCTCC & $264-285$ \\
\hline Solute carrier family 39 (zinc transporter), member 8 & & Reverse CAGGAATCCATATCCCCAAACT & $403-381$ \\
\hline SLC30A1 = ZnT1 & \multirow[t]{2}{*}{ NM_021194 } & Forward CCCCGCAGACCCAGAAAAC & $615-633$ \\
\hline Solute carrier family 30 (zinc transporter), member 1 & & Reverse GTTGTCCAGCCCTATCTTCTTC & $727-706$ \\
\hline SLC30A5 = ZnT5 & \multirow[t]{2}{*}{ NM_022902 } & Forward ACCAAACACCAGTGGATCAAAA & $262-283$ \\
\hline Solute carrier family 30 (zinc transporter), member 5 & & Reverse CAGCAAAGTCCTTAGTGGTCC & $369-349$ \\
\hline \multirow[t]{2}{*}{ T calcium channel alpha1G subunit [Homo sapiens] } & \multirow[t]{2}{*}{$\underline{\text { AF134985 }}$} & Forward AAGAGAAGGAGTAAGGAGAAGCA & $4627-4649$ \\
\hline & & Reverse TGCACAAGTGGTGGACGAG & $4723-4705$ \\
\hline
\end{tabular}

\begin{tabular}{lll}
\hline & Sequence $\left(5^{\prime}->3^{\prime}\right)$ & Location \\
\hline Forward primer & TGGCTGGAATTGACCGCTAC & $128-147$ \\
Reverse primer & CCTTGTGGGCATTAGGTGATTG & $252-231$ \\
\hline
\end{tabular}

\subsection{Effect of $\mathrm{Cd}$ on the intracellular levels of the trace elements}

Our results show that exposure to Cd significantly $(\mathrm{p}<0.01)$ increased $\mathrm{Cd}$ accumulation (Fig. 2) and decreased $\mathrm{Zn}$ concentrations $(\mathrm{p}<0.01)$ in Cd-exposed cells compared to control cells (Fig. 3a). Iron (Fe) and copper $(\mathrm{Cu})$ levels were respectively significantly decreased and increased (Fig. 3a). The effect of Cd on the intracellular levels of $\mathrm{Zn}$, Fe and $\mathrm{Cu}$ was significant from the concentration of $10 \mu \mathrm{M}$ and over.

A low increase in selenium (Se) level was observed in cells exposed

\subsection{Statistical analysis}

Results were expressed as mean \pm standard deviation. All data were analyzed employing one-way ANOVA, followed by the Newman-Keuls test for multiple comparisons. Values of $\mathrm{p}<0.05$ were considered of statistical significance.

\section{Results}

\subsection{Effect of $C d$ on the viability of BJAB cells}

A dose-response curve of $\mathrm{CdCl}_{2}$-induced cell death in $\mathrm{BJAB}$ cells was determined following a $24 \mathrm{~h}$ exposure period to $5,10,20,40,60$, and $80 \mu \mathrm{M}$ (Fig. 1). The mean lethal concentration ( $\mathrm{LC}_{50}$ ) for the $24 \mathrm{~h}$ exposure, defined as the concentration that reduces survival of the cells by $50 \%$, was $40 \mu \mathrm{M}$.

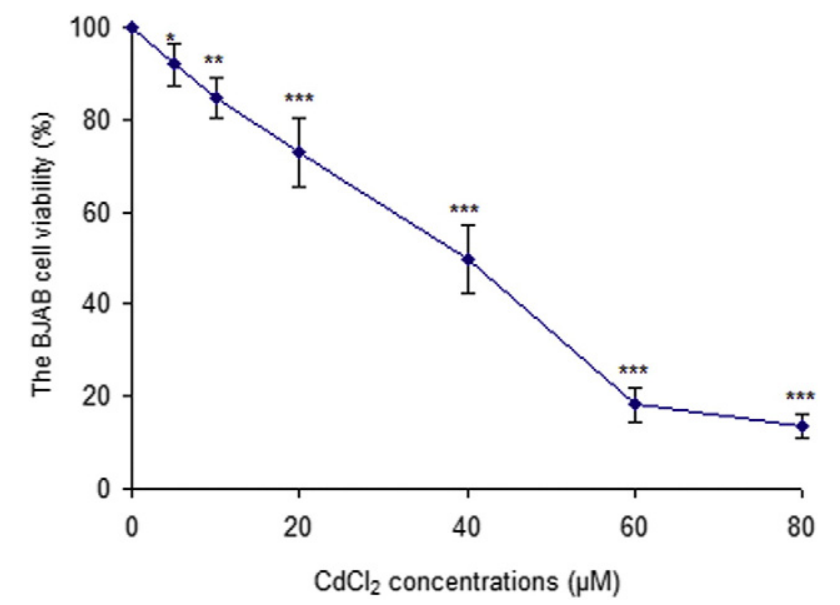

Fig. 1. Effect of exposure to different cadmium (Cd) concentrations on the viability of BJAB cells. Each value represents the mean \pm SD of three independent experiments, with ${ }^{*} \mathrm{p}<0.05,{ }^{* *} \mathrm{p}<0.01$ and ${ }^{* * *} \mathrm{p}<0.001$ compared to the control. level occurred from the Cd concentration of $10 \mu \mathrm{M}$ and over (Fig. 3b).

\subsection{Effect of $C d$ on the antioxidant enzyme activities}

The activity of $\mathrm{Cu} / \mathrm{Zn}$ superoxide dismutase ( $\mathrm{Cu} / \mathrm{ZnSOD}$ ) was significantly inhibited for all concentration of $\mathrm{Cd}$ and the MnSOD activity was only decreased (Fig. 4a) after Cd exposure at $20 \mu \mathrm{M}$, with a concurrent elevation tendency in the activity of catalase (CAT) (Fig. 4b). A decrease in glutathione peroxidase (GPx) was observed with exposure to $40 \mu \mathrm{M}$ Cd.

\subsection{Effect of $C d$ on the oxidative stress parameters}

A significant decrease of the GSH/GSSG ratio (Fig. 5) was obtained when the cells were exposed to 10,20 and $40 \mu \mathrm{M} \mathrm{CdCl}_{2}$. Significantly enhanced MDA levels (Fig. 6) were also observed for the same range of Cd concentrations. The ability of $\mathrm{CdCl}_{2}$ to cause DNA damage was assessed by the comet assay. As shown in Fig. 7 statistically significant DNA damage was observed when BJAB cells were treated with 10,20 , and $40 \mu \mathrm{M}$

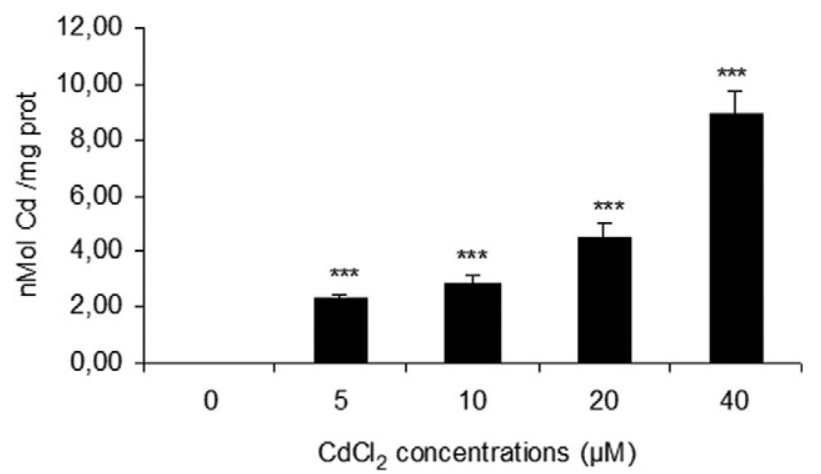

Fig. 2. Intracellular cadmium (Cd) levels in BJAB cells. Each value represents the mean \pm SD of three independent experiments, with ${ }^{* *} \mathrm{p}<0.01$ and $^{* * *} \mathrm{p}<0.001$ compared to the control. 

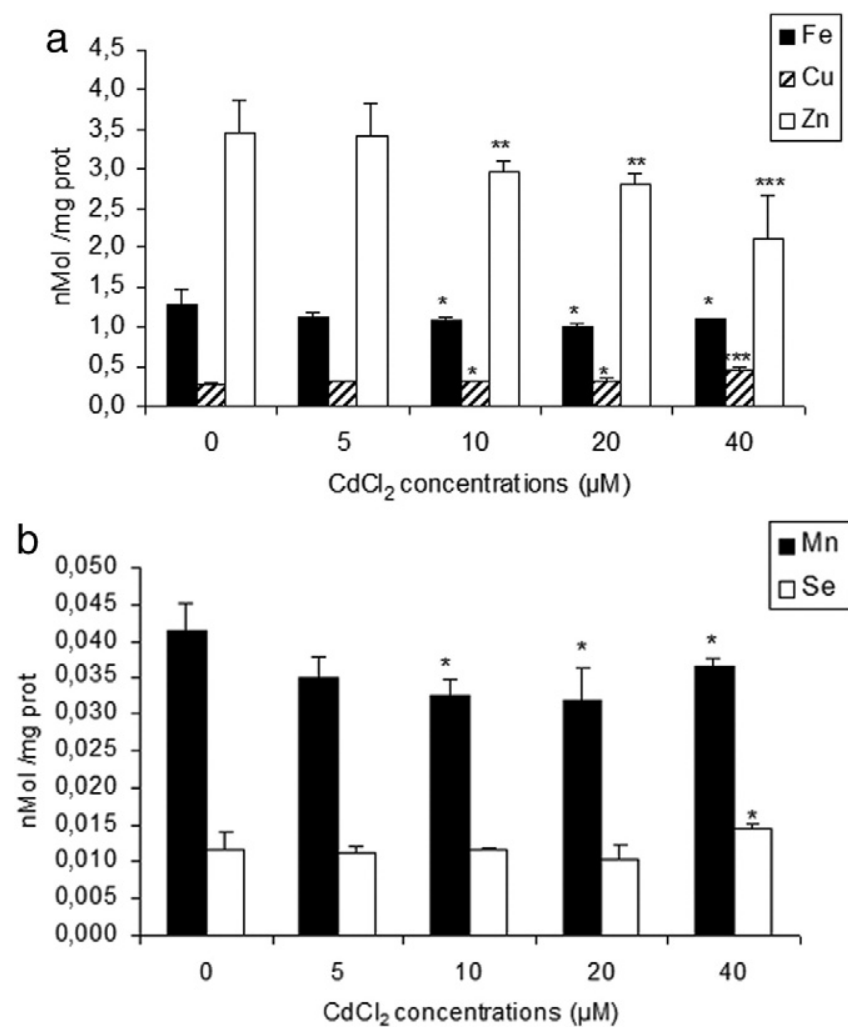

Fig. 3. Effect of cadmium (Cd) on the intracellular level of essential trace elements: (a) Iron (Fe), Copper ( $\mathrm{Cu}$ ), Zinc ( $\mathrm{Zn}$ ); (b) Manganese (Mn), Selenium (Se). Each value represents the mean $\pm S D$ of three independent experiments, with ${ }^{*} \mathrm{p}<0.05,{ }^{* *} \mathrm{p}<0.01$ and *** $\mathrm{p}<0.001$ compared to the control.

$\mathrm{CdCl}_{2}$. The Tail DNA reflected statistically significant differences between the control cells and all the doses employed $(p<0.001)$. In parallel, the $8-O H d G$ (8-Oxo-deoxyguanosine) was increased by of $20 \%$ or more. As shown in Fig. 8 , there was a statistically significant difference between the 8-OHdG levels of exposed and control BJAB cells.

\subsection{Effect of $\mathrm{Cd}$ on the $\mathrm{Zn}$ transporter mRNA expression}

We observed different responses to Cd exposure in the gene expression of the seven transporters we analyzed. There was no significant difference in Zip1, Zip3 and Zip8 expression (Fig. 9) at $5 \mu \mathrm{M}$ of $\mathrm{CdCl}_{2}$ but we showed significant differences for higher levels of Cd exposure. ZnT-1 (Fig. 10a) and ZnT-5 expression (Fig. 10b) respectively increased and decreased significantly according to the augmentation of the Cd concentrations in the culture medium of BJAB cells. ZnT-1 and DMT-1 (Fig. 11) expressions were the highest recorded while the $\mathrm{T}$ calcium channel alpha1G subunit could not be detected.

\subsection{Effect of $C d$ on the MTF-1 and metallothionein expression}

MTF1 mRNA expression (Fig. 12a) increased dose-dependently with increasing $\mathrm{Cd}$ exposure $(\mathrm{p}<0.001)$. As noted, the clone 9 antibody from Dako-MT recognizes both MT-I and MT-II proteins. Western immunoblot (Fig. 12b) analysis showed that control BJAB cells without Cd treatment expressed very low level of MT-I and MT-II proteins, Cd-induced MT protein production in treated cells was evidenced by appearances of conspicuous MT-I and MT-II fused bands on the gel in cells exposed to 10,20 , and $40 \mu \mathrm{M} \mathrm{Cd}$ for $24 \mathrm{~h}$ amounting to 25,34 and 49 -fold of the control, respectively.
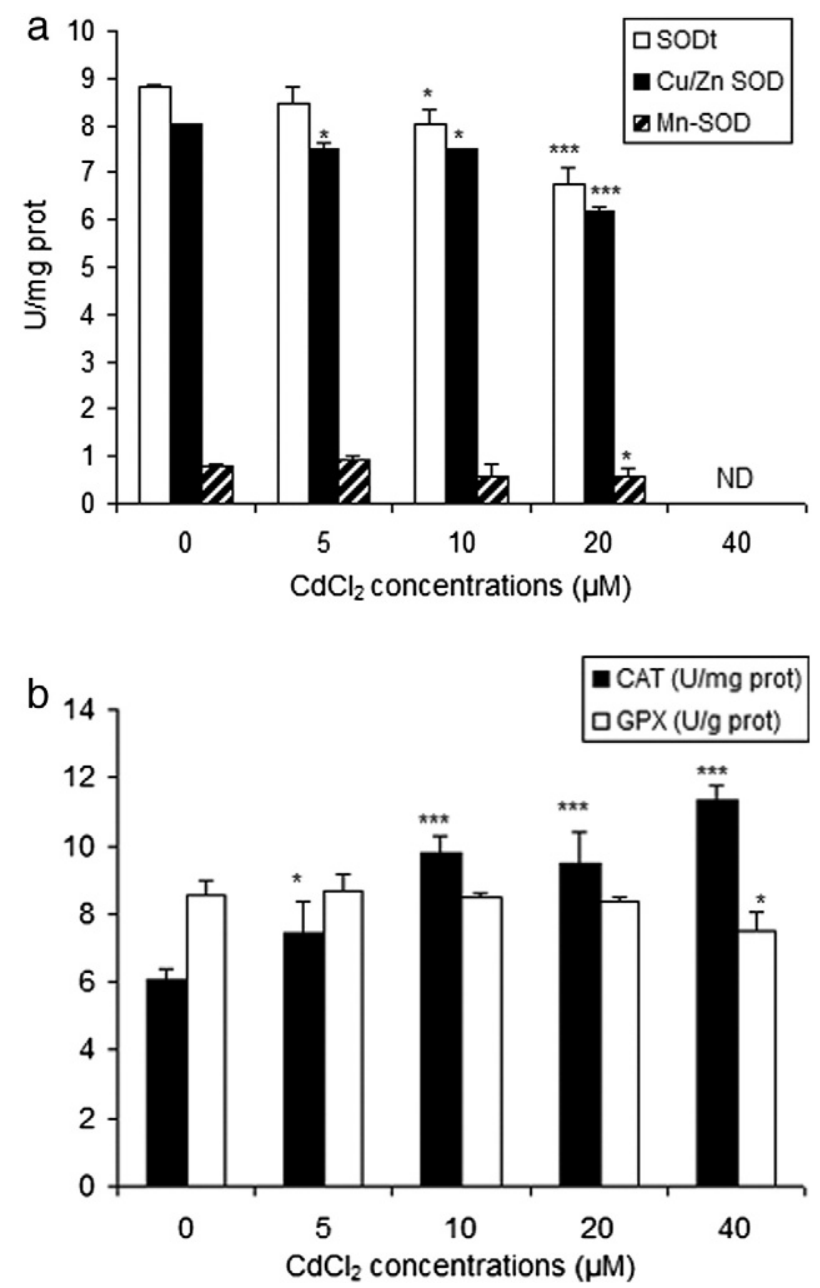

Fig. 4. Effect of cadmium (Cd) on the activities of $\mathrm{Cu} / \mathrm{Zn}$ and Mn superoxide dismutase (a), catalase and glutathione peroxidase (GPx) (b). Each value represents the mean $\pm S D$, with ${ }^{*} \mathrm{p}<0.05$ and $^{* * *} \mathrm{p}<0.001$ compared to the control.

\section{Discussion}

The relevance of the administered doses of $\mathrm{Cd}$ is based on the previous studies and literature data. Both, experimental and epidemiological studies indicate that exposure to Cd may alter the membrane skeleton and contribute to the development of diseases, including cancers of the lung, prostate, kidney, liver and hematopoietic system. Cd causes

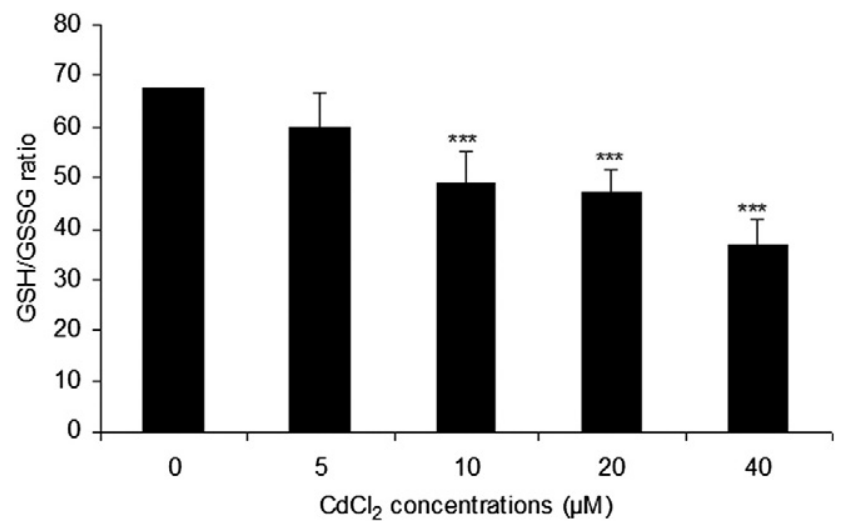

Fig. 5. Changes in GSH/GSSG ratios in BJAB cells following treatment with cadmium (Cd). The results are expressed as the mean \pm SD of three independent experiments, with *** $\mathrm{p}<0.001$ compared to the control. 


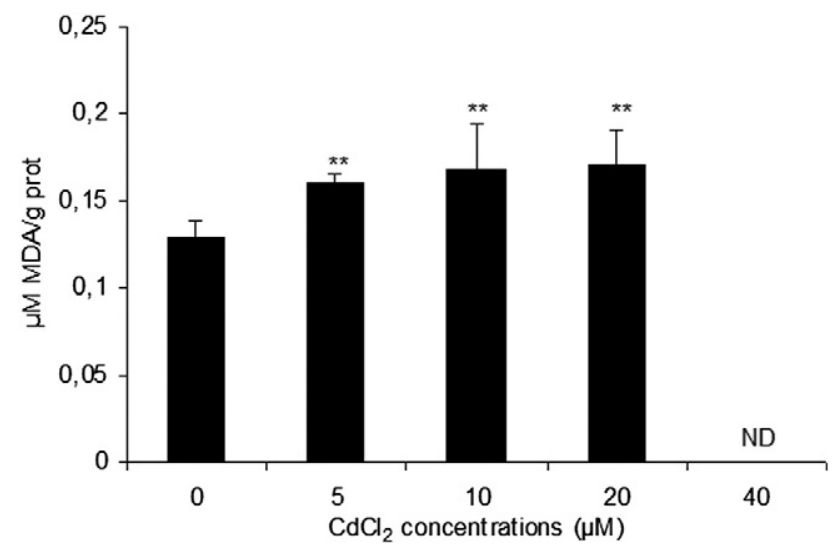

Fig. 6. Effect of cadmium (Cd) on malondialdehyde (MDA) production in BJAB cells. Each value represents the mean $\pm S D$ of three independent experiments, with ${ }^{* *} \mathrm{p}<0.01$ and ${ }^{* * *} \mathrm{p}<0.001$ compared to the control.

damage to cellular structures in various experimental models of acute, prolonged and chronic exposure (Nemmiche et al., 2007; Rogalska et al., 2009). For example, the alterations in the lipid status have been observed as a result of the exposure to 5 and $50 \mathrm{mg} \mathrm{Cd} / \mathrm{l}$, reflecting the exposure in subjects inhabiting moderately contaminated areas or the exposure via habitual cigarette smoking (Rogalska et al., 2009). Persons who have sustained renal damage due to chronic $\mathrm{Cd}$ exposure often have blood or urine Cd levels in a range of $25-50 \mu \mathrm{g} / \mathrm{L}$ or $25-75 \mu \mathrm{g} / \mathrm{g}$ creatinine, respectively. These ranges are usually $1000-3000 \mu \mathrm{g} / \mathrm{L}$ and $100-$ $400 \mu \mathrm{g} / \mathrm{L}$, respectively, in survivors of acute poisoning and may be substantially higher in fatal cases (Baselt, 2008; Nordberg, 2010). In in vitro models, the concentration dependent effects of $\mathrm{Cd}$ have also been highlighted. Generally, submicromolar concentrations lead to proliferation or delayed apoptosis, intermediate concentrations $(10 \mu \mathrm{M})$ can cause various types of cell death, while very high concentrations $(>50 \mu \mathrm{M})$ can cause necrosis (Luevano and Damodaran, 2014).

In the present study, we have shown that Cd uptake in lymphocyte BJAB cells can occur through multiple pathways, mostly ZnT-1 and DMT1. Changes in expression of ZnTs and Zips in response to Cd exposure in human BJAB cells emphasize the involvement of zinc transporters in Cd uptake and metabolism by the cell. ZnT1 was found to be up-regulated, whilst a persistently increased DMT1 mRNA level was noticed. This result emphasizes the important role of ZnT-1 in immune cells and suggests an important contribution of this transporter to immune function. Target cells can only be damaged by $\mathrm{Cd}$ if they possess transport pathways or receptors with an affinity for the toxic metal (Thevenod, 2010).

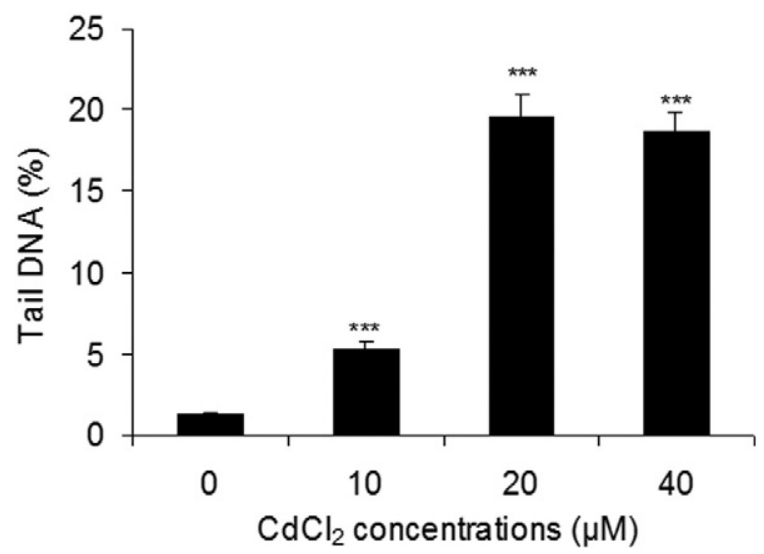

Fig. 7. Effect of cadmium (Cd) on DNA in BJAB cells as assessed with the comet assay. Each value represents the mean $\pm S D$ of three independent experiments, with ${ }^{* *} \mathrm{p}<0.01$ and ${ }^{* * *} \mathrm{p}<0.001$ compared to the control.

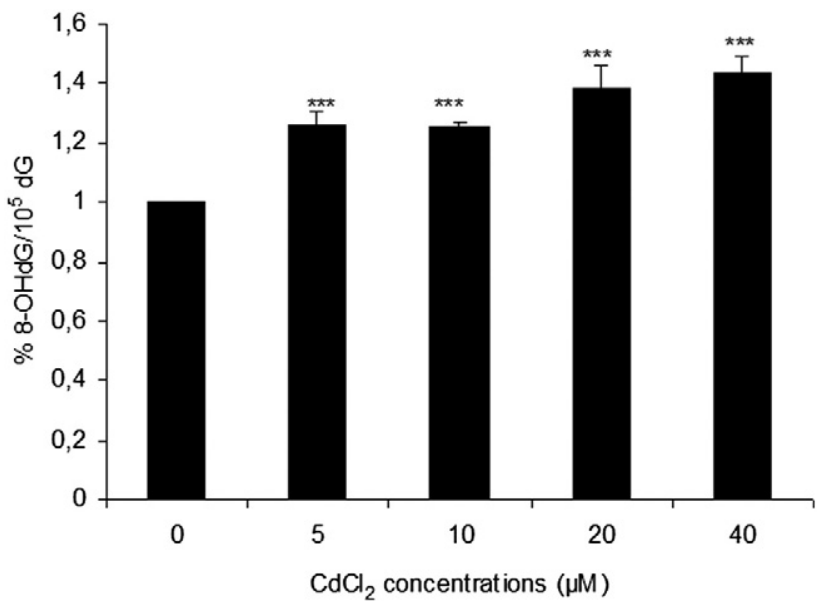

Fig. 8. Effect of cadmium (Cd) on the 8-OHdG levels in BJAB cells. The results are expressed as the mean \pm SD of three independent experiments, with ${ }^{* *} \mathrm{p}<0.01$ and ${ }^{* * *} \mathrm{p}<0.001$ compared to the control.

The ZnT family of Zn transporters mediates the efflux of Zn from cells whereas the influx of zinc into the cells depends on ZIP family of Zn transporters. Most ZnT proteins have been found in intracellular compartments, usually associated with endosomes, Golgi, or endoplasmic reticulum. The localization of some Zip transporters may change according to zinc availability or physiological conditions (Cousins et al., 2006). $\mathrm{Zn}$ homeostasis is regulated through $\mathrm{Zn}$ transporters, $\mathrm{Zn}$ binding molecules, and $\mathrm{Zn}$ sensors. Intracellular $\mathrm{Zn}^{2+}$ rise is associated with upregulation of expression of $\mathrm{Zn}^{2+}$ buffering proteins such as metallothioneins and $\mathrm{Zn}$ transporters. Pathways of $\mathrm{Zn}$ transport and their dysregulation have been linked to specific diseases. ZnT-1 is the only protein that transports zinc across the plasma membrane, whereas the other ZnT transporters assist with zinc sequestration into vesicles called zincosomes.

Recently, it was shown that, in addition to the plasma membrane expressed ZnT-1, one splice variant of ZnT-5 colocalizes with the plasma membrane in Chinese hamster ovary cells (Jackson et al., 2007), and operates in both the uptake and the efflux directions (Valentine et al., 2007). As shown in the present work, both ZnT (1 and 5) and Zip (1, 3 and 8 ) transporters are differentially expressed at the mRNA level in response to changes in $\mathrm{Zn}$ status in BJAB cells.

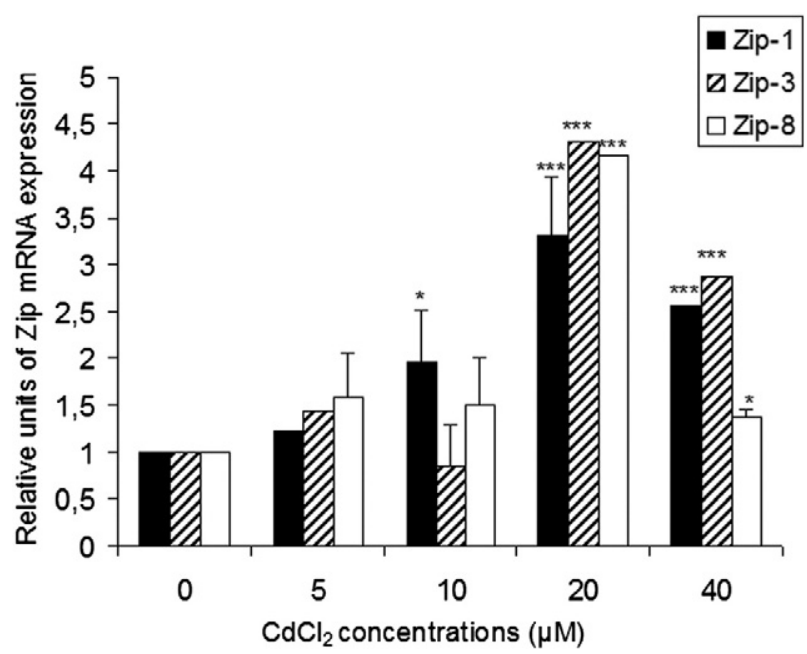

Fig. 9. Effect of various concentrations of cadmium (Cd) on Zips mRNA expression. RT-PCR analysis of total RNA isolated from cells treated with $\mathrm{Cd}$ for $24 \mathrm{~h}$. The results are expressed as the mean \pm SD of three independent experiments, with ${ }^{* *} \mathrm{p}<0.01$ and ${ }^{* * *} \mathrm{p}<0.001$ compared to the control. 

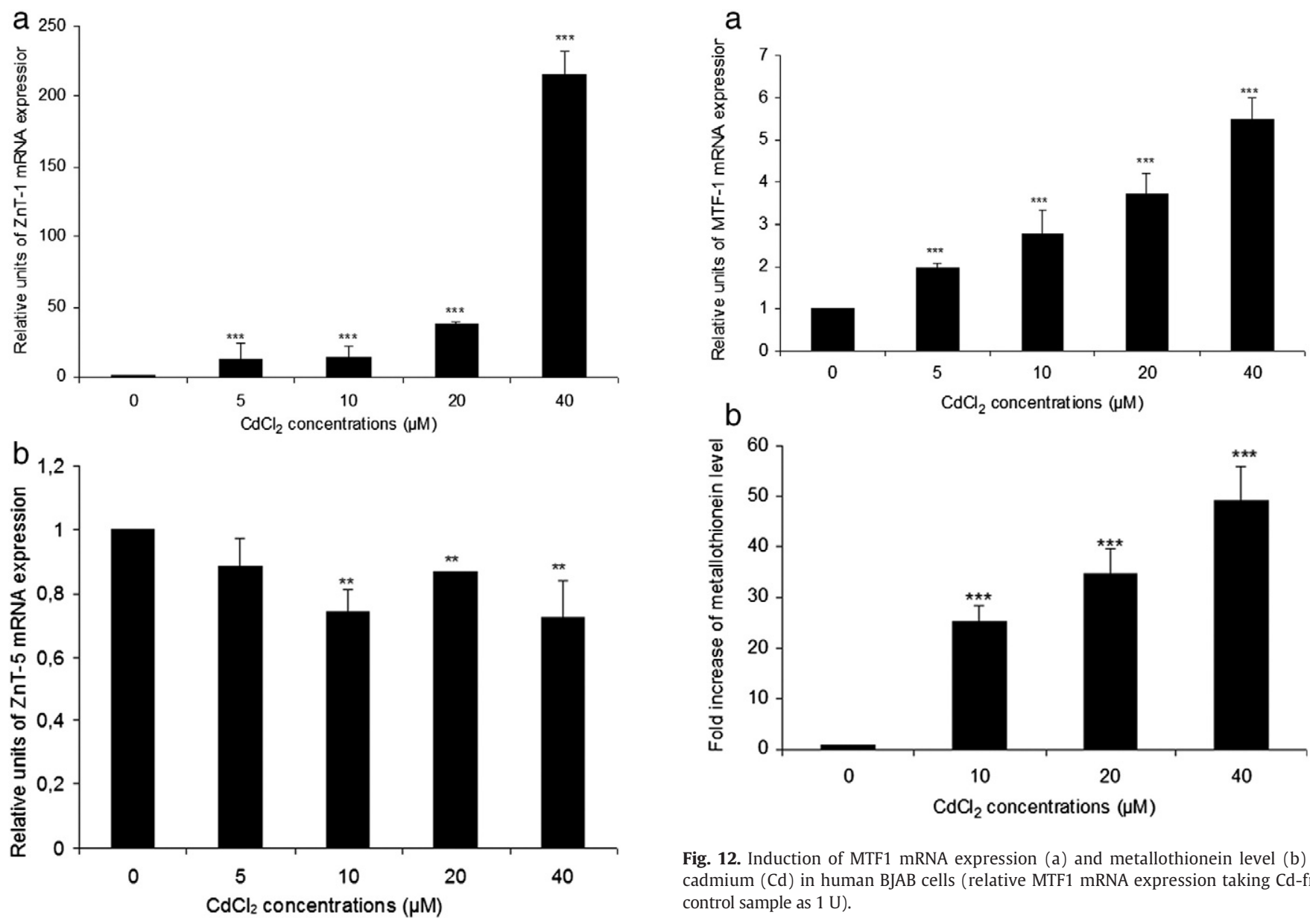

Fig. 10. Effect of cadmium (Cd) on the $\mathrm{Zn}$ transporters mRNA expression in BJAB cells: (a) ZnT-1 (B) ZnT-5. The results are expressed as the mean \pm SD of three independent experiments, with ${ }^{* *} \mathrm{p}<0.01$ and ${ }^{* * *} \mathrm{p}<0.001$ compared to the control.

Zinc-finger structures act as redox-sensitive molecular switches controlling several crucial cellular processes. Oxidative stress, via modification of zinc finger cysteine thiols, leads to a release of $\mathrm{Zn}$ from these structures that may change the levels of intracellular free zinc and, in turn, may exacerbate oxidative stress by impacting glutathione homeostasis and interfere with cellular signaling cascades. Upregulation of ZnT1 in response to lipopolysaccharide stimulation is involved in TLR (Toll-like receptor) signaling by decreasing intracellular zinc levels in dendritic cells (Kitamura et al., 2006). ZnT5 expression is not increased but decreased in zinc-depleted environments.

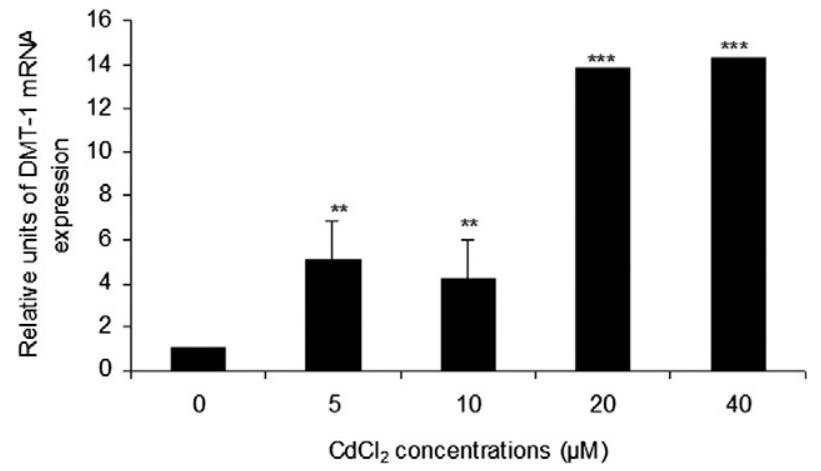

Fig. 11. Effect of cadmium (Cd) on DMT-1 mRNA expression in BJAB cells. The results are expressed as the mean \pm SD of three independent experiments, with ${ }^{* *} \mathrm{p}<0.01$ and *** $\mathrm{p}<0.001$ compared to the control.

Increased mRNA expression of ZIP8, with accompanying lower plasma zinc levels, is reported in sepsis patients (Besecker et al., 2011). ZIP8 mRNA expression is a transcriptional target of NF- $\kappa$ B, and ZIP8 negatively regulates proinflammatory responses through zinc-mediated down

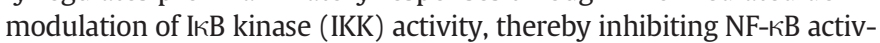
ity (Liu et al., 2013). The leukocyte subsets have been shown to differ strongly in their distribution and their amount of expression of the single transporters (Overbeck et al., 2008). Several studies have provided evidence for the involvement of ZIP8 and ZIP14 in the uptake of Cd into cells (He et al., 2009). The mammalian ZIP8 and ZIP14 transporters are known to be functionally dependent on the extracellular $\mathrm{HCO}_{3}^{-}$concentration. In the rat intestinal brush border membrane vesicles, $\mathrm{Cd}^{2+}$ absorption was found to increase at alkaline pH (Endo et al., 2000) and the efficiency of $\mathrm{Zn}^{2+}$ transport via ZIP transporters was shown to increase with increasing $\mathrm{pH}$.

The over-expression of ZnT-1 enhances the resistance against $\mathrm{Zn}$ toxicity, whereas the silencing of ZnT-1 expression increases heavy metal influx and consequent toxicity (Ohana et al., 2006). However, ZnT-1 transcript levels are markedly reduced in peripheral blood mononuclear cells of zinc-deficient mice (Liuzzi et al., 2004) and our results show that exposure to $\mathrm{Cd}$ significantly increased $\mathrm{Cd}$ accumulation and decreased $\mathrm{Zn}$ and Fe concentrations in BJAB cells. The expression of $\mathrm{ZnTs}$ is tightly and dynamically coupled to changes in $\left[\mathrm{Zn}^{2+}\right]$. The positive mode of ZnT-1 regulation by $\mathrm{Zn}$ supports regulation by metal-responsive transcription factor 1 (MTF1) (Cousins et al., 2006). MTF1 is a nucleocytoplasmic shuttling factor that, in the absence of metal treatment, is predominantly cytoplasmic. Upon heavy metal exposure or cellular stress, MTF1 translocates to the nucleus, where it regulates expression of metallothioneins and other genes. MTF1 has been demonstrated to specifically bind to the MRE to stimulate the gene 
transcription of MT I and ZnT-1 in response to zinc (Langmade et al., 2000; Giedroc et al., 2001).

Metallothioneins (MTs) are a family of low-molecular-weight proteins (6-7 kDa) that are rich in cysteine, which confers a high capacity to bind heavy metal ions in biological systems, and consequently act as free radical scavengers and protect from oxidative damage or heavy metal toxicity (Klaassen et al., 2009). The Cd-induced MTs, both at the mRNA and the protein level, observed in the current study, were accompanied by a significant decrease in $\mathrm{Zn}$ concentration in the lymphocyte $\mathrm{BJAB}$ cells. MT is a prototypical stress-response protein and an extensive collection of studies have documented the involvement of MT in response to numerous types of stress. MT proteins play a role in $\mathrm{Zn}$ homeostasis via the metallothionein(MT)/thionein(T) system to control the concentration of ready available Zn. MTF1 plays a central role in transcription activation of the MT genes which contain at least 6 metal response elements at its promoter regions (Giedroc et al., 2001). Both ZnT-1 and MT expression is modulated by $\mathrm{Zn}$ via the metal responsive element of the transcription factor MTF-1 (Urani et al., 2010).

Cd exposure has been shown to augment MT-I expression in a dosedependent fashion in various mammalian cells. In the majority of cell culture and in vivo experiments, MT induction is associated with protection against subsequent metal, chemical, and other stresses. Fibroblasts from $\mathrm{MT}^{-/-}$murine embryos adapted to cadmium evidenced inhibition of a T-type voltage dependent cationic channel as a way of decreasing Cd uptake (Leslie et al., 2006).

DMT1 is a widely expressed, mammalian ferrous-ion $\left(\mathrm{Fe}^{2+}\right)$ transporter that is energized by the $\mathrm{H}^{+}$electrochemical potential gradient and all four isoforms of human DMT1 function as metal-ion transporters of equivalent efficiency (Mackenzie et al., 2007). It has been demonstrated that iron-deficient diet can increase intestinal DMT1 expression as well as cadmium body burden in rats, thereby implying that the intestinal cadmium uptake may be linked to the uptake of iron (Ryu et al., 2004). The results of Bannon et al. (2003) provide evidence for the direct involvement of DMT1 in Caco-2 cells for the uptake of iron and cadmium.

Our previous studies indicate that cellular pro-oxidative stress induced by $\mathrm{Cd}$ is most likely mediated by disruption of redox homeostasis associated to a mishandling of redox-active transition metals and genotoxic effects in the lymphocyte cells (Nemmiche et al., 2007, 2011). These effects exerted by Cd may be modulated the network signal transduction pathways involved in the regulation of redox sensitive transcription factors (e.g., NF-kB and Nrf2) (Nemmiche et al., 2012). The present study indicated that $\mathrm{Cd}$ caused a significant decrease in $\mathrm{Zn}$ content and in the activity of $\mathrm{Cu} / \mathrm{Zn}-\mathrm{SOD}$ in BJAB cells. Appropriate copper and zinc accessibility to $\mathrm{Cu} / \mathrm{ZnSOD}$ can influence its structural geometry, redox activity and protein function (Miao and Clair, 2009). Antioxidant and other cell redox state modulating enzyme systems act as the firstline defense against ROS in all cellular compartments and also extracellularly (Nemmiche et al., 2007). Also, we observed that DNA damage in lymphocyte cells is well correlated with the presence of oxidative stress.

The Comet assay measures DNA damage as the extent of single and double-strand breaks, alkali-labile sites, cross-links, and incomplete excision repair sites. Results in the comet assay can be influenced by DNA repair processes in a complex way. Hydroxyl radical is the principal damaging species involved in the formation of DNA strand breaks, modified bases, abasic sites, sugar alterations, and DNA-protein cross-links. The measurement of 8-0xodeoxyguanosine is important because this lesion which is known to be mutagenic is commonly used as a marker of oxidative stress. The absence of efficient detoxification processes in lymphocyte $\mathrm{BJAB}$ cells was associated with increased 8-Oxo-deoxyguanosine (8-OHdG) formation as well as decreased rates of 8-OHdG repair in the cells resulting in the inhibition of DNA damage repair. Current evidence indicate that exposure to $\mathrm{Cd}$ induces genomic instability (Filipic, 2011). Cd inactivates mammalian 8-oxoguanineDNA glycosylase (mOGG1) as well as 8 -oxodG-triphosphate pyrophosphohydrolase (8-oxo-dGTPase) activities required for the removal of 8-oxo-dG from the deoxynucleotide pool (Zharkov and Rosenquist, 2002). In nucleotide excision repair, Cd inhibited the first step, which is recognition of DNA damage. If the repair process is inhibited, an increment in DNA migration might be expected in the comet assay because of the persistence of DNA lesions which lead to strand breakage by themselves and/or because of an accumulation of DNA strand breaks related to ongoing DNA repair (Mouron et al., 2004). The potential of Cd to inhibit DNA damage repair has been demonstrated by several investigators (Giaginis et al., 2006). Exposure of alveolar epithelial cells to Cd significantly reduced the activity of formamidopyrimidine DNA glycosylase, an enzyme involved in the recognition and removal of oxidative DNA damage such as 8-hydroxyguanine and 8-hydrohydroxyadenine (Potts et al., 2001). Both oxidative stress and inhibition of repair of oxidative DNA damage undoubtedly play a role in $\mathrm{Cd}$-induced carcinogenesis.

\section{Conclusion}

In summary, our current findings reveal that multiple transporters are involved in the uptake of Cd by lymphocyte BJAB cells. Once crossed the membrane barrier, the intracellular homeostasis of $\mathrm{Zn}$ and $\mathrm{Cd}$ is primarily regulated by two proteins, ZnT-1 and metallothioneins (Urani et al., 2010); the potential role of zinc-binding proteins in delivering transition metals to antioxidant enzymes remains to be established. Further studies need to be addressed to understand the mechanism of ZnT-1 up-regulation by $\mathrm{Cd}$ and to evaluate interactions between Cd, MT and $\mathrm{Zn}$ transporters in the human BJAB cells. It will also be important to determine the patterns of expression of the other $\mathrm{Zn}$ transporters.

\section{Conflict of interest}

There are no conflicts of interest.

\section{Transparency document}

The Transparency document associated with this article can be found, in the online version.

\section{Transparency document}

The Transparency document associated to this article can be found, in the online version.

\section{Acknowledgements}

The authors are grateful to Alain Favier and Florence De Fraipont (DBI, Grenoble) for helpful.

\section{References}

Akerboom, T.P., Sies, H., 1981. Assay of glutathione, glutathione disulfide, and glutathione mixed disulfides in biological samples. Methods Enzymol. 77, 373-382.

Bannon, D.I., Roger, A., Lees Peter, S.J., Bressler, J.P. 2003. Effect of DMT1 knockdown on iron, cadmium, and lead uptake in Caco-2 cells. Am J Physiol Cell Physiol 284, 44-50.

Baselt, R., 2008. Disposition of Toxic Drugs and Chemicals in Man. 8th edition. Biomedical Publications, Foster City, CA, pp. 212-214.

Beers, R.F., Sizer, I.W., 1952. A spectrophotometric method for measuring the breakdown of hydrogen peroxide by catalase. J. Biol. Chem. 195, 133-139.

Besecker, B.Y., Exline, M.C., Hollyfield, J., Phillips, G., Disilvestro, R.A., Wewers, M.D. Knoell, D.L., 2011. A comparison of zinc metabolism, inflammation, and disease severity in critically ill infected and noninfected adults early after intensive care unit admission. Am. J. Clin. Nutr. 93, 1356-1364.

Bridges, C.C., Zalups, R.K., 2005. Molecular and ionic mimicry and the transport of toxic metals. Toxicol. Appl. Pharmacol. 204, 274-308.

Chang, X., Jin, T., Chen, L., et al., 2009. Metallothionein I isoform mRNA expression in peripheral lymphocytes as a biomarker for occupational cadmium exposure. Exp. Biol. Med. 234, 666-672. 
Cousins, R.J., Liuzzi, J.P., Lichten, L.A., 2006. Mammalian zinc transport, trafficking, and signals. J. Biol. Chem. 281, 24085-24089.

Endo, T., Kimura, O., Saitoh, H., Sakata, M., 2000. Secretory transport of cadmium through intestinal brush border membrane via $\mathrm{H}+$-antiport. Toxicology 150, 129-136.

Filipic, M., 2011. Mechanisms of cadmium induced genomic instability. Mutat. Res. Fundam. Mol. Mech. Mutagen. http://dx.doi.org/10.1016/j.mrfmmm.2011.09.002.

Flohe, L., Gunzler, W.A., 1984. Assays of glutathione peroxidase. Methods Enzymol. 105, 114-121.

Fujishiro, H., Doi, M., Enomotobc, S., Himeno, S., 2011. High sensitivity of RBL-2H3 cells to cadmium and manganese: an implication of the role of ZIP8. Metallomics http://dx. doi.org/10.1039/c1mt00020a.

Gedik, C.M., Collins, A., 2005. Establishing the background level of base oxidation in human lymphocyte DNA: results of an interlaboratory validation study. FASEB J. 19, 82-84.

Giaginis, C., Gatzidou, E., Theocharis, S., 2006. DNA repair systems as targets of cadmium toxicity. Toxicol. Appl. Pharmacol. 213, 282-290.

Giedroc, D.P., Chen, X., Apuy, J.L., 2001. Metal response element (MRE) binding transcription factor-1 (MTF-1): structure, function, and regulation. Antioxid. Redox Signal. 3 , 577-596.

Haase, H., Ober-Blöbaum, J.L., Engelhardt, G., Hebel, S., Rink, L., 2010. Cadmium ions induce monocytic production of tumor necrosis factor-alpha by inhibiting mitogen activated protein kinase dephosphorylation. Toxicol. Letters 198, 152-158.

He L, Wang B, Hay EB, Nebert D. W. (2009). Discovery of ZIP transporters that participate in cadmium damage to testis and kidney. Toxicol. Appl. Pharmacol. 238, 250-257

IARC, International Agency for Research on Cancer, 1993. Monographs on the Evaluation of the Carcinogenic Risks to Humans, Beryllium, Cadmium, Mercury and Exposures in the Glass Manufacturing Industry. IARC Scientific Publications, Lyon, France, pp. 119-238.

Jackson, K.A., Helston, R.M., McKay, J.A., O'Neill, E.D., Mathers, J.C., Ford, D., 2007. Splice variants of the human zinc transporter ZnT5 (SLC30A5) are differentially localized and regulated by zinc through transcription and mRNA stability. J. Biol. Chem. 282, 10423-10431.

Kitamura, H., Morikawa, H., Kamon, H., Iguchi, M., Hojyo, S., Fukada, T., Yamashita, S., Kaisho, T., Akira, S., Murakami, M., Hirano, T., 2006. Toll-like receptor-mediated regulation of zinc homeostasis influences dendritic cell function. Nat. Immunol. 7, 971-977.

Klaassen, C.D., Liu, J., Diwan, B.A., 2009. Metallothionein protection of cadmium toxicity. Toxicol. Appl. Pharmacol. 238, 215-220.

Langmade, S.J., Ravinda, R., Daniels, P.J., Andrews, G.K., 2000. The transcription facto MTF-1 mediates metal regulation of the mouse ZnT1 gene. J. Biol. Chem. 275, 34803-34809.

Leslie, E.M., Liu, J., Klaassen, C.D., Waalkes, M.P., 2006. Acquired cadmium resistance in metallothionein-I/II $(-/-)$ knockout cells: role of the T-type calcium channe Cacnalpha1G in cadmium uptake. Mol. Pharmacol. 69, 629-639.

Lévesque, M., Martineau, C., Jumarie, C., Moreau, R., 2008. Characterization of cadmium uptake and cytotoxicity in human osteoblast-like MG-63 cells. Toxicol. Appl. Pharmacol. 231, 308-317.

Lichten, L.A., Cousins, R.J., 2009. Mammalian zinc transporters: nutritional and physiologic regulation. Annu. Rev. Nutr. 29, 153-176.

Liu, M.J., Bao, S., Galvez-Peralta, M., Pyle, C.J., Rudawsky, A.C., Pavlovicz, R.E., Killilea, D.W., Li, C., Nebert, D.W., Wewers, M.D., Knoell, D.L., 2013. ZIP8 regulates host defense through zinc-mediated inhibition of NF-kB. Cell Rep. 3, 386-400.

Liuzzi, J.P., Cousins, R.J., 2004. Mammalian zinc transporters. Annu. Rev. Nutr. 24 151-172.

Liuzzi, J.P., Bobo, J.A., Lichten, L.A., Samuelson, D.A., Cousins, R.J., 2004. Responsive transporter genes within the murine intestinal-pancreatic axis form a basis of zinc homeostasis. Proc. Natl. Acad. Sci. U. S. A. 101, 14355-14360.

Luevano, J., Damodaran, C., 2014. A review of molecular events of cadmium-induced carcinogenesis. J. Environ. Pathol. Toxicol. Oncol. 33 (3), 183-194.

Luparello, C., Sirchia, R., Longo, A., 2010. Cadmium as a transcriptional modulator in human cells. Crit. Rev. Toxicol. 1-8.

Mackenzie, B., Takanaga, H., Hubert, N., Rolfs, A., Hediger, M.A., 2007. Functional properties of multiple isoforms of human divalent metal-ion transporter 1 (DMT1) Biochem. J. 403, 59-69.

Marklund, S., Marklund, G., 1974. Involvement of the superoxide anion radical in the autoxidation of pyrogallol and a convenient assay for superoxide dismutase. Eur. J. Biochem./FEBS 47, 469-474.
Martineau, C. Abed, E., Médina, G., Jomphe, L.A., Mantha, M., Jumarie, C., Moreau, R., 2010. Involvement of transient receptor potential melastatin-related 7 (TRPM7) channels in cadmium uptake and cytotoxicity in MC3T3-E1 osteoblasts. Toxicol. Lett. 199, 357-363.

Miao, L., Clair, D.K.S., 2009. Regulation of superoxide dismutase genes: implications in disease. Free Radic. Biol. Med. 47, 344-356.

Mizzen, C.A., Cartel, N.J., Yu, W.H., Fraser, P.E., McLachlan, D.R., 1996. Sensitive detection of metallothioneins-1, -2 and -3 in tissue homogenates by immunoblotting: a method for enhanced membrane transfer and retention. J. Biochem. Biophys. Methods 32 (2), 77-83.

Mouron, S.A., Grillo, C.A., Dulout, F.N., Golijow, C.D., 2004. A comparative investigation of DNA strand breaks, sister chromatid exchanges and K-ras gene mutations induced by cadmium salts in cultured human cells. Mutat. Res. 568, 221-231.

Naha, P.C., Byrne, H.J., 2013. Generation of intracellular reactive oxygen species and genotoxicity effect to exposure of nanosized polyamidoamine (PAMAM) dendrimers in PLHC-1 cells in vitro. Aquat. Toxicol. 132-133 (2013), 61-72.

Naha, P.C., Davoren, M., Lyng, F.M., Byrne, H.J., 2010. Reactive oxygen species (ROS) induced cytokine production and cytotoxicity of PAMAM dendrimers in J774A.1 cells. Toxicol. Appl. Pharmacol. 246 (1-2), 91-99.

Naha, P.C., Chhour, P., Cormode, D.P., 2015. Systematic in vitro toxicological screening of gold nanoparticles designed for nanomedicine applications. Toxicol. in Vitro 29 (2015), 1445-1453.

Nemmiche, S., Chabane-Sari, D., Guiraud, P., 2007. Role of $\alpha$-tocopherol in cadmium-induced oxidative stress in Wistar rat's blood, liver and brain. Chemico-Biol. Int. 170, 221-230.

Nemmiche, S., Chabane-Sari, D., Kadri, M., Guiraud, P., 2011. Cadmium chloride induced oxidative stress and DNA damage in the human Jurkat T cell line is not linked to intracellular trace elements depletion. Toxicol. In Vitro 25, 191-198.

Nemmiche, S., Chabane-Sari, D., Kadri, M., Guiraud, P., 2012. Cadmium-induced apoptosis in the BJAB human B cell line: involvement of PKC/ERK1/2/JNK signaling pathways in HO-1 expression. Toxicology 300, 103-111.

Nordberg, G.F., 2010. Biomarkers of exposure, effects and susceptibility in humans and their application in studies of interactions among metals in China. Toxicol. Lett. $192,45-49$

Ohana, E., Sekler, I., Kaisman, T., Kahn, N., Cove, J., Silverman, W.F., Amsterdam, A., Hershfinkel, M., 2006. Silencing of ZnT-1 expression enhances heavy metal influx and toxicity. J. Mol. Med. 84, 753-763.

Overbeck, S., Uciechowski, P., Ackland, M.L., Ford, D., Rink, L., 2008. Intracellular zinc homeostasis in leukocyte subsets is regulated by different expression of zinc exporters ZnT-1 to ZnT-9. J. Leukoc. Biol. http://dx.doi.org/10.1189/jlb.0307148.

Potts, R.J., Bespalov, I.A., Wallace, S.S., Melamede, R.J., Hart, B.A., 2001. Inhibition of oxidative DNA repair in cadmium-adapted alveolar epithelial cells and the potential involvement of metallothionein. Toxicology 161, 25-38.

Rogalska, J., Brzoska, M.M., Roszczenko, A., Moniuszko-Jakoniuk, J., 2009. Enhanced zinc consumption prevents cadmium-induced alterations in lipid metabolism in male rats. Chem. Biol. Interact. 177, 142-152.

Ryu, D.Y., Lee, S.J., Park, D.W., Choi, B.S., Klaassen, C.D., Park, J.D., 2004. Dietary iron regulates intestinal cadmium absorption through iron transporters in rats. Toxicol. Lett. $152,19-25$.

Thevenod, F., 2010. Catch me if you can! Novel aspects of cadmium transport in mammalian cells. Biometals http://dx.doi.org/10.1007/s10534-010-9309-1.

Urani, C., Melchioretto, P., Gribaldo, L., 2010. Regulation of metallothioneins and ZnT-1 transporter expression in human hepatoma cells HepG2 exposed to zinc and cadmium. Toxicol. In Vitro 24, 370-374.

Valentine, R.A., Jackson, K.A., Christie, G.R., Mathers, J.C., Taylor, P.M., Ford, D., 2007. ZnT5 variant $B$ is a bidirectional zinc transporter and mediates zinc uptake in human intestinal Caco-2 cells. J. Biol. Chem. 282 (19), 14389-14393.

Zalups, R.K., Ahmad, S., 2003. Molecular handling of cadmium in transporting epithelia. Toxicol. Appl. Pharmacol. 186, 163-188.

Zharkov, D.O., Rosenquist, T.A., 2002. Inactivation of mammalian 8-oxoguanine-DNA glycosylase by cadmium(II): implications for cadmium genotoxicity. DNA Repair 1 , 661-670. 